\title{
Colour and texture characteristics of "Užička" fermented sausage produced in the traditional way
}

\author{
Vesković Moračanin Slavical, Karan Dragica ${ }^{1}$, Trbović Dejana ${ }^{1}$, Okanović Djordje², Džinić Natalija³, \\ Jokanović Marija ${ }^{3}$
}

A b s $t r a c t$ : With the aim to preserve the quality of traditional fermented sausages and provide the continuity in production, a task of this work was to determine the quality characteristics of "Užička" sausage, traditional fermented sausage from Serbia. "Užička" sausage was produced from beef of I and II category, pork of II category, firm fatty tissue, nitrite salt, sodium chloride and spices (sweet and hot ground paprika, black pepper and garlic). Sausages were manufactured in traditional smokehouse - smoking, fermentation, ripening and drying lasted 21 days. Sausages were made in three replicates. The paper presents the most important chemical quality parameters (protein, moisture, fat and total ash content, sodium chloride content, $\mathrm{pH}$ value and nitrite content) with the description of sensory properties (colour, surface of cut, coherence, fatty tissue quality, tenderness, and overall impression) and the results of colour and texture measurements ("Chromameter" CR-400 and "INSTRON" model 4301), at the end of the production process. Results of the sensory evaluation showed the most desirable properties in sausages produced in the January (when climatic conditions were optimal for the production), and the results of colour and texture measurements were in agreement with the results of the sensory evaluation.

Key words: "Užička"sausage, chemical analysis, sensory analysis, colour and texture instrumental analysis.

\section{Introduction}

Dry fermented sausages have always been appreciated and demanded by consumers for their quality - recently, they have also become the subject of growing interest in research area. Available literature provides information about the authentic ways of fermented sausages production with special emphasis on microclimate conditions. Also, detailed microbiological, physico-chemical, sensory and other investigations have been conducted in this area (Ambrosiadis et al., 2004; Morretti et al., 2004; Turubatović et al., 2004; Cocolin et al., 2005; Gasparik-Reichardt et al., 2005; Vesković Moračanin and Obradović, 2009). Flavour and other properties of traditionally fermented sausages are influenced by the selection and quality of basic raw material, metabolic activity of the present epiphytic microflora, physical and chemical changes due to drying, smoking, enzymatic breakdown of proteins and fats, external factors (temperature, relative humidity and air circulation), duration of ripening and other (Mendoza, 2001).

"Užička" sausage and "kulen" are the most popular national representatives of this group of sausages. Traditional (household) production of these sausages takes place in colder periods of the year (November- January). Pork is the basic component, obtained from animals (often "Mangulica" breed) slaughtered on the same day of manufacture. Used meat is of high quality (mostly shoulder, sometimes leg). In the cases when meat of lower quality is used (higher content of fat and connective tissue), it has to be minced. Sometimes, beef can also be added. Other ingredients are common salt, sweet or hot ground paprika and garlic. Sausages are smoked for several days in traditional smokehouses (twice a day) and air-dried till the end of the winter (Ikonić et al., 2011).

Such way of production was the only viable option in the past regarding food preservation since no other means were available at the time. Sausages had

Acknowledgments: The results are part of integrated and interdisciplinary research project No. III 46009, funded by the Ministry of Education, Science and Technological Development of Republic of Serbia.

\footnotetext{
${ }^{1}$ Institute of Meat Hygiene and Technology, Kaćanskog 13, 1000 Belgrade, Republic of Serbia;

${ }^{2}$ University of Novi Sad, Institute of Food Tehnology, Novi Sad, Bulevar cara Lazara 1, 21000 Novi Sad, Republic of Serbia;

3University of Novi Sad, Faculty of Tehnology, Bulevar cara Lazara 1, 21000 Novi Sad, Republic of Serbia.
}

Corresponding author: Vesković Moračanin Slavica, slavica@inmesbgd.com 
high nutritional value and desirable aroma of well riped meat and together with the flavour from added spices, this type of product was tastier than common dried meat. The specific raw material composition and production conditions (natural and diverse animal feeding, smoking in traditional smokehouses, air drying) were some of the factors that contributed to the overall taste and specific sensory properties compared to industrially produced fermented sausages. National market today offers dry fermented sausages with similar sensory properties, but, unfortunatelly, overemphasized acidic flavour, often unacceptable for the consumers (Petrohilou and Rantsios, 2005; Vesković Moračanin et al., 2011).

In order to preserve the quality of traditionally fermented sausages and to provide consistency in production process, we set the task to investigate sensory properties of "Užička" sausage manufactured in traditional manner and to determine colour and firmness of the sausages using instrumental analysis.

\section{Materials and methods}

\section{Sausage production}

"Užička" sausage was manufactured in traditional way in craft meat plant Nikola Brković in Zlatibor. Sausages were manufactured according to the traditional recipe, in three batches: the first batch was manufactured in November (the first fermentation - IF), the second in December, (the second fermentation - IIF) and and the third in January (the third fermentation - IIIF). Basic properties, ingredients and ripening procedure of "Užička" sausage are shown in table 1.
"Užička" sausage was produced from beef of I and II category, II category of pork, firm fatty tissue, nitrite salt, sodium chloride and spices (sweet and hot ground paprika, black pepper and garlic). Frozen fatty tissue pieces were added to the cutter, followed by chilled meat, previously ground up to $20 \mathrm{~mm}$ granulation, and finally nitrite salt, sodium chloride and spices were added. After the homogenisation and granulation of $Æ 8 \mathrm{~mm}$, mixture was stuffed into bovine small intestine $Æ 37-40 \mathrm{~mm}$. Mixture temperature was $-3^{\circ} \mathrm{C}$. Sausages were hand shaped in the form of a horseshoe. After the stuffing, sausages were left to drain and were kept in low humidity air so that the suface dried, i.e. they were prepared for the smoking process. Sausages were smoked in traditional smokehouse using beech wood. Smoking, fermentation, ripening and drying lasted 21 days.

\section{Chemical analysis}

Nitrogen content was determined by the Kjeldahl method and protein estimated by multiplying the nitrogen content by 6.25 (Kjeltec Auto 1030 Analyzer, Tecator, Sweeden). Moisture content was determined by drying the sample at $103 \pm 2^{\circ} \mathrm{C}$ to constant weight (SRPS ISO 1442:98). Fat was extracted from the sample using petroleum ether by Soxhlet apparatus (SRPS ISO 1444:98). Ash content was determined by combustion at $550 \pm 25^{\circ} \mathrm{C}$ (SRPS ISO 936:99). Sodium chloride was determined by $A O A C$ 24.010 method. $\mathrm{pH}$ value was determined by $\mathrm{pH}$ meter Cyber Scan pH 510 and water activity was measured by aw meter FA - st/1 GBX. Nitrite was determined after proteins precipitation and filtration, by addition of sulfanilamide and N-(1-naphthyl)

Table 1. Properties, ingredients and ripening procedure of "Užička" sausage

Tabela 1. Svojstva, sastojci i postupci zrenja „Užičke“ kobasice

\begin{tabular}{|c|c|c|c|c|c|}
\hline $\begin{array}{l}\text { Type of } \\
\text { fermented } \\
\text { sausage/ } \\
\text { Vrsta } \\
\text { fermentisane } \\
\text { kobasice }\end{array}$ & $\begin{array}{l}\text { Sausage } \\
\text { dimensions } \\
\text { and weight/ } \\
\text { Dimenzije i } \\
\text { težina kobasice }\end{array}$ & $\begin{array}{l}\text { Casing/ } \\
\text { Omotač }\end{array}$ & Ingredients/Sastojci & $\begin{array}{l}\text { Quantity }(100 \mathrm{~kg}) / \\
\text { Količina }(100 \mathrm{~kg})\end{array}$ & $\begin{array}{l}\text { Ripening process/ } \\
\text { Proces zrenja }\end{array}$ \\
\hline $\begin{array}{l}\text { "Užička" } \\
\text { sausagel } \\
\text { "Užička" } \\
\text { kobasice }\end{array}$ & $\begin{array}{l}ø 40 \mathrm{~mm} \\
41 \mathrm{~cm} \text { in lenght/ } \\
\text { dužina } 700 \mathrm{~g}\end{array}$ & $\begin{array}{l}\text { Natural } \\
\text { (beef small } \\
\text { intestine)/ } \\
\text { Prirodni } \\
\text { (goveđe tanko } \\
\text { crevo) }\end{array}$ & $\begin{array}{l}\text { Beef/Goveđe meso } \\
\text { Pork/Svinjsko meso } \\
\text { Firm fat tissue/ } \\
\text { Čvrsto masno tkivo } \\
\text { Nitrite salt/Nitritna so } \\
\text { Sodium chloride/ } \\
\text { Natrijum-hlorid } \\
\text { Spice/Začin }\end{array}$ & $\begin{array}{l}70 \mathrm{~kg} \\
20 \mathrm{~kg} \\
10 \mathrm{~kg} \\
2.5 \mathrm{~kg} \\
300 \mathrm{~g} \\
850 \mathrm{~g}\end{array}$ & $\begin{array}{l}\text { Ripening: } 21 \text { days } \\
\text { at } 2-13^{\circ} \mathrm{C} \text {, } \\
64 \%-88 \% \text { rel. hum. } \\
\text { Vreme zrenja: } 21 \\
\text { dan, na } 2-13^{\circ} \mathrm{C} \text {, rel. } \\
\text { vlaž. } 64-88 \%\end{array}$ \\
\hline
\end{tabular}


ethylenediaminedihydrochloride (SRPS ISO 2918:99), intensity of colour is measured at $538 \mathrm{~nm}$ by spectrophotometer JenWay 6405 .

\section{Sensory analyses}

Using quantitative - descriptive test (Baltić, 1992; SRPS 6658, 2001), with grading scale from one to ten (1-unacceptable, 10-optimum), at the end of each production, sensory properties of sausages were assessed (colour, surface cut, consistency - connection degree of meat and fatty tissue, fatty tissue quality, tenderness, and overall impression). Five person panel was assembled in order to evaluate sensory properties. Panelists were previously tested for detection and recognition of various tastes (SRPS 3972, 2001) and odours (SRPS 5496, 2002).

Color measurements were carried out using photo colorimeter MINOLTA CHROMA METER CR-400 (Minolta Co., Ltd., Osaka, Japan). Colour characteristics are given in the CIE L*a*b* system. Three measurements were taken on three fresh cut surfaces of sausages from each batch. Tenderness and firmness were determined by measuring cutting force and penetration force using Instron
4301 instrument. Tenderness was determined as cutting force, using Warner-Bratzler shear blade (force $0.25 \mathrm{kN}$, crosshead speed $100 \mathrm{~mm} / \mathrm{min}$ ). The samples were prepared by cutting 8 one-inch diameter cylinders from each sausage using the mold. Firmness was determined as force needed for penetration through $1 \mathrm{~cm}$ thick slice (force $0.25 \mathrm{kN}$, crosshead speed $100 \mathrm{~mm} / \mathrm{min}$ ).

The results were statistically processed by calculating mean $(\mathrm{X})$ and standard deviation (SD) for each sensory property. Coefficient of variation $(\mathrm{Cv})$ was also calculated as relative measure of dispersion showing the differences between multiple measurements (\%). Statistical calculations were carried out using Microsoft Excell.

\section{Results and discussion}

Chemical composition (moisture, fat, protein, sodim chloride) of "Užička" sausage during ripening is presented in Table 2.

As the amount of water in sausages decreased during production, the correlative increase of fat and protein content occurred. The average fat content of

Table 2. Changes of chemical parameters of "Užička" sausage during ripening (mean $\pm \mathrm{SD}$ )

Tabela 2. Promene hemijskih parametara „Užičke“ kobasice tokom zrenja (srednja vrednost \pm SD)

\begin{tabular}{|c|c|c|c|c|c|c|c|}
\hline \multirow{2}{*}{$\begin{array}{l}\text { Chemical } \\
\text { parameters/ } \\
\text { Hemijski parametri }\end{array}$} & \multirow{2}{*}{$\mathbf{F}$} & \multicolumn{6}{|c|}{ Days /Dan } \\
\hline & & $0^{\text {th }}$ & $2^{\text {nd }}$ & $4^{\text {th }}$ & $7^{\text {th }}$ & $14^{\text {th }}$ & $21^{\text {st }}$ \\
\hline \multirow{3}{*}{$\begin{array}{l}\text { Moisture,\%/ } \\
\text { Vlaga,\% }\end{array}$} & I & $56,38 \pm 0,11$ & $54,46 \pm 0,16$ & $51,30 \pm 0,14$ & $46,50 \pm 0,18$ & $41,81 \pm 0,12$ & $35,19 \pm 0,17$ \\
\hline & II & $60,41 \pm 0,15$ & $58,46 \pm 0,18$ & $55,16 \pm 0,13$ & $49,10 \pm 0,12$ & $43,70 \pm 0,16$ & $37,43 \pm 0,18$ \\
\hline & III & $61,78 \pm 0,12$ & $59,66 \pm 0,19$ & $57,05 \pm 0,15$ & $56,70 \pm 0,14$ & $43,88 \pm 0,18$ & $36,69 \pm 0,16$ \\
\hline \multirow{3}{*}{$\begin{array}{l}\text { Fat, \%/ } \\
\text { Mast, \% }\end{array}$} & I & $24,33 \pm 0,20$ & $25,13 \pm 0,15$ & $26,78 \pm 0,13$ & $28,91 \pm 0,12$ & $30,84 \pm 0,11$ & $35,38 \pm 0,17$ \\
\hline & II & $18,76 \pm 0,19$ & $19,22 \pm 0,14$ & $20,30 \pm 0,12$ & $22,51 \pm 0,10$ & $26,91 \pm 0,09$ & $28,43 \pm 0,15$ \\
\hline & III & $16,07 \pm 0,09$ & $17,33 \pm 0,12$ & $19,33 \pm 0,13$ & $18,73 \pm 0,14$ & $23,41 \pm 0,15$ & $28,31 \pm 0,14$ \\
\hline \multirow{3}{*}{$\begin{array}{l}\text { Proteins,\%/ } \\
\text { Proteini,\% }\end{array}$} & I & $15,55 \pm 0,12$ & $16,79 \pm 0,15$ & $18,08 \pm 0,09$ & $20,12 \pm 0,13$ & $20,33 \pm 0,13$ & $23,88 \pm 0,12$ \\
\hline & II & $17,02 \pm 0,20$ & $18,10 \pm 0,20$ & $20,11 \pm 0,09$ & $23,25 \pm 0,12$ & $24,01 \pm 0,07$ & $27,21 \pm 0,10$ \\
\hline & III & $18,34 \pm 0,09$ & $19,00 \pm 0,08$ & $19,43 \pm 0,07$ & $20,26 \pm 0,07$ & $26,94 \pm 0,08$ & $28,72 \pm 0,04$ \\
\hline \multirow{3}{*}{$\begin{array}{l}\text { Sodium chloride,\%/ } \\
\text { Natrijum-hlorid,\% }\end{array}$} & I & $2,26 \pm 0,01$ & $3,10 \pm 0,01$ & $3,29 \pm 0,01$ & $3,51 \pm 0,01$ & $3,82 \pm 0,01$ & $4,47 \pm 0,01$ \\
\hline & II & $2,98 \pm 0,01$ & $3,28 \pm 0,01$ & $3,52 \pm 0,01$ & $3,95 \pm 0,01$ & $4,61 \pm 0,01$ & $5,12 \pm 0,01$ \\
\hline & III & $2,93 \pm 0,01$ & $3,06 \pm 0,01$ & $3,23 \pm 0,01$ & $3,37 \pm 0,01$ & $4,55 \pm 0,01$ & $4,75 \pm 0,01$ \\
\hline
\end{tabular}

$\mathrm{SD}$ - standard deviation/SD- standardna devijacija

F- fermentation/F- fermentacija 


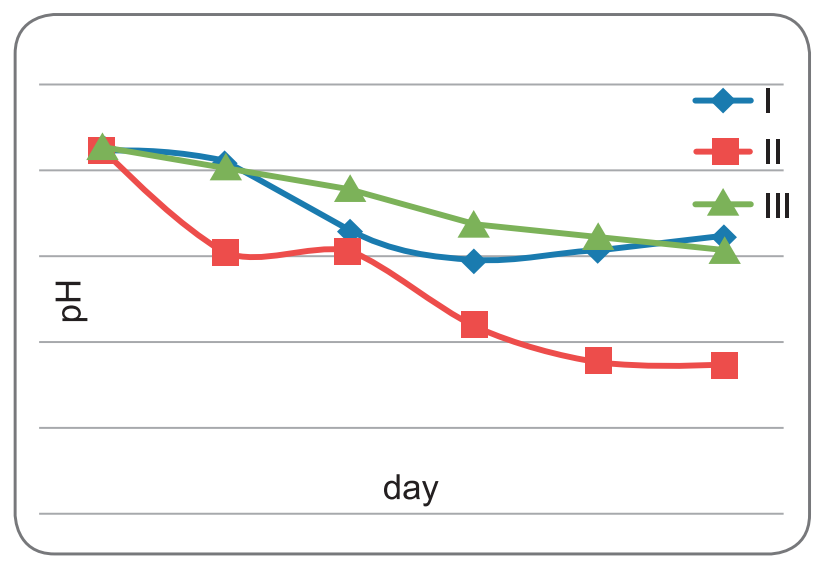

Figure 1. Changes of $\mathrm{pH}$ value of sausage during ripening

Slika 1. Promene $\mathrm{pH}$ vrednosti kobasice tokom zrenja

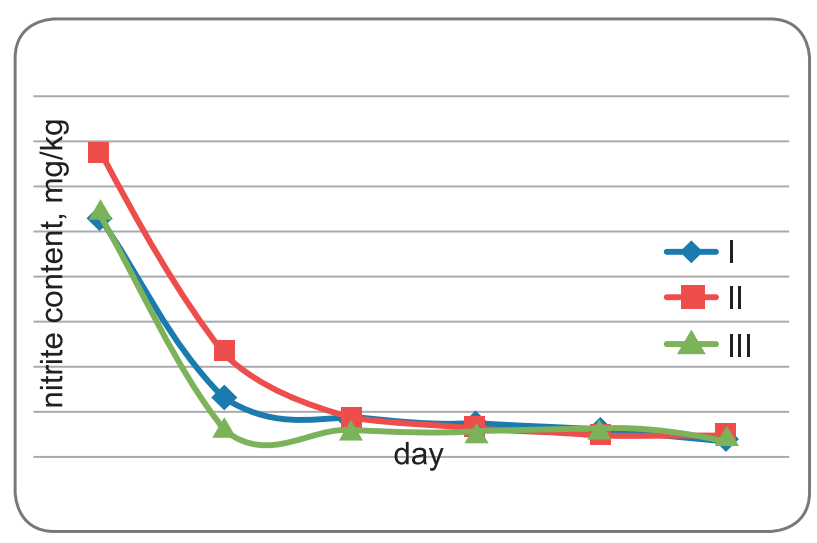

Figure 3. Changes of nitrite content of sausage during ripening

Slika 3. Promene sadržaja nitrita u kobasicama tokom zrenja

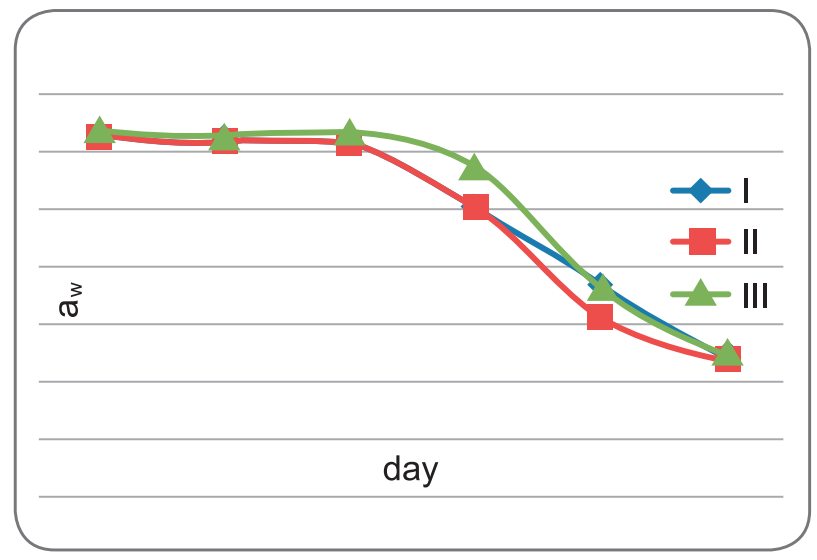

Figure 2. Changes of $a_{w}$ value of sausage during ripening

Slika 2. Promene $\mathrm{a}_{\mathrm{w}}$ vrednosti kobasice tokom zrenja

"Užička" sausage at the end of production, $21^{\text {st }}$ day in all three fermentation procedures (IF, IIF, IIIF) was $30.7 \%$, and the average protein content was $26.60 \%$. From an initial value of $5.25, \mathrm{pH}$ value intensively decreased to 4.97 , till $7^{\text {th }}$ day of fermentation). Subsequently, $\mathrm{pH}$ remained unchanged till the end of production. (Fig.1). Water activity $\left(\mathrm{a}_{\mathrm{w}}\right)$ followed the same trend (Fig. 2).

Changes of nitrite content of "Užička" sausage during ripening are presented in Fig. 3. The average nitrite content on the first day of production was $58.39 \mathrm{mg} / \mathrm{kg}$ and rapidly decreased till the $2^{\text {nd }}$ day of fermentation. On the $21^{\text {st }}$ day, residual nitrite level was $4.29 \mathrm{mg} / \mathrm{kg}$. Nitrite content decreased because they oxidize myoglobin to metmyoglobin and partly were oxidized to nitrates.

Results of sensory evaluation of "Užička" sausage are shown in Table 3.

Table 3. Results of sensory evaluation of "Užička" sausage at the end of production process/

Tabela 3. Rezultati senzorske ocene „Užičke“ kobasice na kraju proizvodnog procesa

\begin{tabular}{|c|c|c|c|c|c|c|c|c|c|c|c|c|}
\hline \multirow{3}{*}{$\begin{array}{l}\text { Fermentation/ } \\
\text { Fermentacija }\end{array}$} & \multicolumn{12}{|c|}{$\begin{array}{l}\text { Sensory properties/ } \\
\text { Senzorska svojstva }\end{array}$} \\
\hline & \multicolumn{2}{|c|}{$\begin{array}{c}\text { Colour/ } \\
\text { Boja }\end{array}$} & \multicolumn{2}{|c|}{$\begin{array}{c}\text { Surface of cut/ } \\
\text { Površina } \\
\text { preseka }\end{array}$} & \multicolumn{2}{|c|}{$\begin{array}{l}\text { Coherence/ } \\
\text { Koherentnost }\end{array}$} & \multicolumn{2}{|c|}{$\begin{array}{c}\text { Fat tissue } \\
\text { quality/ } \\
\text { Kvalitet masn. } \\
\text { tkiva }\end{array}$} & \multicolumn{2}{|c|}{$\begin{array}{l}\text { Tenderness/ } \\
\text { Nežnost }\end{array}$} & \multicolumn{2}{|c|}{$\begin{array}{c}\text { Overall } \\
\text { impression/ } \\
\text { Opšti utisak }\end{array}$} \\
\hline & $\mathrm{X} \pm \mathrm{SD}$ & $\mathrm{Cv}$ & $\mathrm{X} \pm \mathrm{SD}$ & $\mathrm{Cv}$ & $\mathrm{X} \pm \mathrm{SD}$ & $\mathrm{Cv}$ & $\mathrm{X} \pm \mathrm{SD}$ & $\mathrm{Cv}$ & $\mathrm{X} \pm \mathrm{SD}$ & $\mathrm{Cv}$ & $\mathrm{X} \pm \mathrm{SD}$ & $\mathrm{Cv}$ \\
\hline I & $8.40 \pm 0.50$ & 5.95 & $8.30 \pm 0.45$ & 5.39 & $8.80 \pm 0.45$ & 5.08 & $8.40 \pm 0.42$ & 4.98 & $8.90 \pm 0.42$ & 4.70 & $8.80 \pm 0.27$ & 3.11 \\
\hline II & $7,60 \pm 0.50$ & 6.58 & $7.40 \pm 0.42$ & 5.65 & $7.30 \pm 0.45$ & 6.13 & $7.30 \pm 0.45$ & 6.13 & $7.10 \pm 0.22$ & 3.15 & $7.50 \pm 0.50$ & 6.67 \\
\hline III & $8,50 \pm 0.50$ & 5.88 & $8.70 \pm 0.27$ & 3.15 & $8.60 \pm 0.50$ & 5.81 & $8.00 \pm 0.35$ & 4.42 & $8.20 \pm 0.50$ & 6,10 & $8.90 \pm 0.42$ & 4.70 \\
\hline
\end{tabular}

$\mathrm{X}$ - mean /X - srednja vrednost

$\mathrm{SD}$ - standard deviation /SD - standardna varijacija

$\mathrm{Cv}-$ coefficient of variation, $\% / \mathrm{Cv}-$ koeficijent varijacije 
Table 4. Results of instrumental determination of cut surface colour of "Užička" sausage at the end of production process in CIE L*a*b* system/

Tabela 4. Rezultati instrumentalnog određivanja boje površine preseka „Užičke“ kobasice na kraju proizvodnog procesa u CIE L *a *b* sistemu

\begin{tabular}{|c|c|c|c|c|c|c|}
\hline \multirow{2}{*}{$\begin{array}{c}\text { Fermentation/ } \\
\text { Fermentacija }\end{array}$} & \multicolumn{2}{|c|}{$\begin{array}{c}\text { Light intensity } \boldsymbol{L}^{*} \\
\text { Intenzitet svetlosti } \mathbf{L}^{*}\end{array}$} & \multicolumn{2}{c|}{$\begin{array}{c}\text { Share of red } \boldsymbol{a}^{*} \\
\text { Udeo crvene } \boldsymbol{a}\end{array}$} & \multicolumn{2}{c|}{$\begin{array}{c}\text { Share of yellow } \boldsymbol{b} * \\
\text { Udeo žute } \mathbf{b}^{*}\end{array}$} \\
\cline { 2 - 7 } & $\mathrm{X} \pm \mathrm{SD}$ & $\mathrm{Cv}$ & $\mathrm{X} \pm \mathrm{SD}$ & $\mathrm{Cv}$ & $\mathrm{X} \pm \mathrm{SD}$ & $\mathrm{Cv}$ \\
\hline I & $45.36 \pm 3.59$ & 7.87 & $15.52 \pm 1.64$ & 10.60 & $7.34 \pm 0.81$ & 11.04 \\
\hline II & $43.82 \pm 4.16$ & 9.49 & $17.83 \pm 1.58$ & 8.86 & $7.22 \pm 0.62$ & 8.59 \\
\hline III & $35.26 \pm 2.37$ & 6.72 & $19.27 \pm 0.93$ & 4.83 & $7.88 \pm 1.11$ & 14.09 \\
\hline
\end{tabular}

$\mathrm{X}$ - mean /X - srednja vrednost

$\mathrm{SD}$ - standard deviation /SD - standardna varijacija,

$\mathrm{Cv}$ - coefficient of variation, $\% / \mathrm{Cv}$ - koeficijent varijacije, $\%$

"Užička" sausage from the first fermentation (IF) was manufactured in November, when the micro-climatic conditions for the smoking and drying were favourable, so the sausages from this fermentation were evaluated with high grades for the studied properties ranging from 8.3 to 9.00 . Also, sausages from the third fermentation (IIIF), produced in January, were evaluated with high grades for the studied properties ranging from 8.00 to 9.00 . "Užička" sausage from the second fermentation (IIF), produced in late December, was rated with slightly lower scores, ranging from 7.00 to 7.70 .

It can be concluded that the climate conditions were favourable for sensory properties of fermented sausages. The most favourable climate conditions for traditional fermented sausages production are in the period of the year with low temperatures and high relative humidity (Karan et al., 2012).

The scores for colour were the highest (8.50) for sausages produced in January (IIIF). Overall impression was also the highest for this group (8.90) compared to sausages from IIF (8.80) and IF (7.50). Significant differences were observed in colour assessment. The results of sensory evaluation of "Užička" sausage from IIIF were in accordance with the results obtained by the group of authors for similar product (Saičić et al., 2006; Vesković Moračanin and Obradović, 2009). Morretti et al., 2004 have evaluated sensory properties of traditional sausage from Sicily produced from meat of autochtonous pigs (Nero Siciliano), where ripening of one group was carried out in traditional way (Sicilian taverna), while the ripening of the second group was conducted in industrial conditions. The authors have concluded that the ripening of sausages in controlled conditions can be done during the entire year, while in traditional production, ripening cannot take place in summer time due to high temperatures.

Results of instrumental colour measurements of "Užička" are shown in Table 4.

The results of cut surface colour show that sausages produced in November (IIF) were slightly lighter ( $\mathrm{L}^{*}$-value) compared to sausages produced in December (IF) and January (IIIF), however the differences were not statistically significant. The highest share of red was recorded in sausages from IIIF. Share of yellow $\left(b^{*}\right)$ was the lowest in sausages from IIF.

With the moisture loss the concentration of myoglobin in product increased, and on the other hand dehydrated muscle tissue absorbed a greater amount of light resulting in darker colour of the product, i.e. lower $L^{*}$ value (Aguirrezábal et al., 2000). It should be noted that red hot paprika powder had the great influence on the $a^{*}$ value in analyzed sausages . Also, $b^{*}$ value of analyzed sausages could probably be related to the presence of yellow carotenoids coming from paprika powder (Gimeno et al., 2000).

Table 5 shows the results of determination of firmness and tenderness of "Užička" sausage from all three groups by measuring penetration force and cutting force.

The highest penetration force (measure of firmness) was recorded in samples of "Užička" sausage produced in November (IF), compared to sausages produced in December (IIF) and January (IIIF). However, higher cutting force was measured in sausages from IF and IIF group compared to sausages from IIIF group. The reasons for such results are to be found in different climate conditions. At the same time, higher meat content in fermented sausages results in higher firmness. This is consistent with results obtained by other authors (Vuković et al., 2009). 
Table 5. Parameters of firmness and tenderness of "Užička" sausage at the end of production process/

Tabela 5. Parametri čvrstine i nežnosti „Užička“ kobasice na kraju proizvodnog procesa

\begin{tabular}{|c|c|c|c|c|}
\hline \multirow{2}{*}{$\begin{array}{l}\text { Fermentation/ } \\
\text { Fermentacija }\end{array}$} & \multicolumn{2}{|c|}{$\begin{array}{c}\text { Penetration force, (N)/ } \\
\text { Sila penetracije, (N) }\end{array}$} & \multicolumn{2}{c|}{$\begin{array}{c}\text { Cutting force, (N)/ } \\
\text { Sila sečenja, (N) }\end{array}$} \\
\cline { 2 - 5 } & $\mathrm{X} \pm \mathrm{SD}$ & $\mathrm{CV}$ & $\mathrm{X} \pm \mathrm{SD}$ & $\mathrm{CV}$ \\
\hline I & $23.55 \pm 3.57$ & 15.20 & $44.37 \pm 5.62$ & 12.70 \\
\hline II & $18.88 \pm 1.96$ & 10.40 & $39.64 \pm 1.78$ & 4.49 \\
\hline III & $12.49 \pm 1.67$ & 13.40 & $24.84 \pm 2.91$ & 11.70 \\
\hline
\end{tabular}

$\mathrm{X}$ - mean /X - srednja vrednost

$\mathrm{SD}$ - standard deviation /SD - standardna varijacija,

$\mathrm{Cv}$ - coefficient of variation, $\% / \mathrm{Cv}-$ koeficijent varijacije, $\%$

The impression of the assessors is that the overall process of ripening and drying for the sausage of the IIIF group should last for another ten days, so that the properties of the product would probably got to a point higher ratings.

Firmness of sausages is partly the result of protein coagulation at low $\mathrm{pH}$, and also partly the result of decreasing moisture content (Bozkurt and Bayram, 2006). Values of firmness, recorded for all groups of sausages, were lower comparing with chorizo de Pamplona (Gimeno et al., 2000), but similar to those of Italian low-acid (Spaziani et al, 2009) and slow fermented sausage analyzed by Olivares et al (2010).

\section{Conclusions}

"Užička" sausages produced in November (first fermentation-IF) and January (third fermentation
- IIIF) had very desirable sensory attributes, while the sausages produced in December (the second fermentation - IIF) were evaluated with slightly lower scores. Overall impression of "Uzička" sausages from third fermentation (8.90) and first fermentation (8.80) had better assessment of overall impression than sausages from second fermentation (7.50). The results of instrumental determination of colour and firmness of "Užička" sausage samples were in agreement with the results of sensory evaluation. The investigated properties were better in sausages produced in January compared to the ones produced in December and November.

On the basis of the obtained results it can be concluded that the best sensory properties of traditional fermented Užička sausages could be achieved when production is carried out in late winter which is the common period for traditional production of "Užička" sausage.

\section{References}

Aguirrezábal M., Mateo J., Domínguez C., Zumalacárregui M., 2000. The effect of paprika, garlic and salt on rancidity in dry sausages. Meat Science, 54, 77-81.

Ambrosiadis J., Soultos N., Abrahim A., Bloukas J.G., 2004. Physicochemical, microbiological and sensory attributes for the characterization of Greek traditional sausages. Meat Science, 66, 279-287.

Baltić M., 1992. Kontrola namirnica. Institut za higijenu i tehnologiju mesa. Beograd, 1-335.

Bozkurt H., Bayram M., 2006. Colour and textural attributes of sucuk during ripening. Meat Science, 73, 344-350

Cocolin L., Urso R., Rantsiou K., Comi G., 2005. Identification, Sequencing and Characterization of Lactic Acid Bacteria Genes Responsible for Bacteriocin Production. Tehnologija mesa, 3-4, 162-172.
Gasparik-Reichardt J., Toth Sz., Cocolin G., Comi G., Drosinos E., Cvrtila Z., Kozačinski L., Smajlović A., Saičić S., Borović B., 2005. Technological, physicochemical and microbiological characteristics of traditionally fermented sausages in Mediterranean and central European countries. Tehnologija mesa, 3-4, 143-153.

Gimeno O., Ansorena D., Astiasaran I., Bello J., 2000. Characterization of chorizo de Pamplona: instrumental measurements of colour and texture. Food Chemistry, 69, 95-200.

Ikonić P., Tasić T., Petrović L., Jokanović M., Savatić S., Tomović V., Džinić N., Šojić B., 2011. Effect of drying and ripening methods on proteolysis and biogenic amines formation in traditional dry-fermented sausage Petrovská klobása. Food and Feed Research, 38, 1, 1-8. 
Karan D., Vesković Moračanin S., Babić J., Parunović N., Okanović Dj., Džinić N., Jokanović M., 2012. Sensory properties of traditionally fermented "Levačka" sausage. Tehnologija mesa, 53, 1, 43-49.

Mendoza E., Garcia M. L., Casas C., Selgas M. D., 2001. Inulin as fat substitute in low fat, dry fermented sausages. Meat Science, 57, 387-393.

Moretti V. M., Madonia G., Diaferia C., Mentasti T., Paleari M.A., Panseri S., Pirone G., Gandini G., 2004. Chemical and microbiological parameters and sensory attributes of a typical Sicilian salami ripened in different conditions. Meat Science, 66, 845-854.

Olivares A., Navarro J. L., Salvador A., Flores M., 2010. Sensory acceptability of slow fermented sausages based on fat content and ripening time. Meat Science 86, 251-257.

Ordonez J. A., Hierro E. M., Bruna J. M., Hoz L., 1999. Changes in the components of dry-fermented sausages during ripening. Critical Reviews in Food Science and Nutrition, 39, 329-367.

Petrohilou I., Rantsios A., 2005. Task and goals of the project: "Safety of traditional fermented sausages: Research on protective cultures and bacteriocins", funded by the INCO-DEV Programme. Tehnologija mesa, 3-4, $138-142$.

Saičić S., Karan D., Vesković Moračanin S., 2006. "Sremska" sausage with the addition of protective cultures and bactriocins. $52^{\text {th }}$ International Congress of Meat Science and Technology, $13^{\text {th }}-18^{\text {th }}$ August, Dublin.
Spaziani M., Del Torre M., Stecchini M. L., 2009. Changes of physicochemical, microbiological, and textural properties during ripening of Italian low-acid sausages, Proteolysis, sensory and volatile profiles. Meat Science, 81, 77-85.

SRPS ISO 3972, 2001. Sensory analysis - Methodology Method of investigating sensitivity of taste.

SRPS ISO 5496, 2002. Sensory analysis - Methodology - Initiation and training of assessors in the detection and recognition of odours.

SRPS ISO 6658, 2001. Sensory analysis - Methodology - General guidance.

Turubatović L., Hadžiosmanović M., Čaklovica F., Petrohilou I., 2004. Results of physicochemical and sensorial investigation of fermented sausages during fermentation and rippening process. $50^{\text {th }}$ International Congress of Meat Science and Technology, Helsinki, 204.

Vesković Moračanin S., Obradović D., 2009. Mikrobiološki ekosistem tradicionalnih fermentisanih kobasica u Srbiji - mogućnosti stvaranja sopstvenih starter kultura. Tehnologija mesa, 50, 1-2, 60-67.

Vesković Moračanin S., Karan D., Okanović Đ., Jokanović M., Džinić N., Parunović N., Trbović D., 2011. Colour and texture properties of traditionally fermented "Sremska" sausage. Tehnologija mesa, 52, 2, 245-251.

Vuković I., Saičić S., Vasilev D., Tubić M., Vasiljević N., Milanović-Stevanović M., 2009. Neki parametri kvaliteta i nutritivna vrednost funkcionalnih fermentisanih kobasica. Tehnologija mesa, 50, 1-2, 68-74.

\title{
Karakteristike boje i teksture fermentisane „Užičke“6 kobasice proizvedene na tradicionalan način
}

\author{
Vesković Moračanin Slavica, Karan Dragica, Trbović Dejana, Okanović Đorđe, Džinić Natalija, \\ Jokanović Marija
}

R e z i m e: U cilju očuvanja kvaliteta tradicionalnih fermentisanih kobasica i obezbeđivanja kontinuiteta u njihovoj proizvodnji, zadatak ovog rada je bio da se utvrdi kvalitet „Užičke “ kobasice, koja je tradicionalni srpski fermentisani proizvod od mesa. , Užička“ kobasica je proizvedena od goveđeg mesa I i II kategorije, svinjskog mesa II kategorije, čvrstog masnog tkiva, nitritne soli, natrijumhlorida i začina (slatka i ljuta mlevena paprika, crni biber i beli luk). Kobasice su dimljene u tradicionalnim pušnicama - dimljenje, fermentacija, zrenje $i$ sušenje trajalo je 21 dan. Kobasice su proizvedene u tri ponavljanja. U radu su prikazani najvažniji hemijski parametri kvaliteta (sadržaj proteina, sadržaj vode, masti i pepela, natrijum-hlorida, pH vrednost, sadržaj nitrita) sa opisom senzornih svojstava (boja, izgled površine preseka, koherentnost, kvalitet masnog tkiva, nežnost i opšti utisak) i rezultati instrumentalnog merenja boje i teksture (,, Chromameter “ CR - 400 i,NSTRON“ model 4301) na kraju proizvodnog procesa. Rezultati senzorske ocene su pokazali da najpoželjnija svojstva imaju kobasice iz treće fermentacije, proizvedene u januaru (kada su klimatski uslovi bili optimalni za proizvodnju), kao i da su rezultati instumentalnog merenja boje i teksture u saglasnosti sa rezultatima senzorskih ispitivanja.

Ključne reči: , Užička” kobasica, hemijske analize, senzorne analize, instrumentalna analiza boje i teksture.

Paper received: 18.10 .2013 .

Paper corrected: 30.10 .2013 .

Rad accepted: 26.11.2013. 